\title{
THE CONCEPT OF A SUSTAINABLE APPROACH TO CORPORATE REAL ESTATE MANAGEMENT
}

\author{
Ewa Ziemba, Associate Professor, Ph.D., D.Sc. \\ Faculty of Finance and Insurance \\ University of Economics in Katowice \\ e-mail:ewa.ziemba@ue.katowice.pl
}

Katarzyna Śmietana, Ph.D.

Faculty of Finance and Insurance

University of Economics in Katowice

e-mail:katarzyna.smietana@ue.katowice.pl

\section{Tomasz Ramian, Ph.D.}

Faculty of Finance and Insurance

University of Economics in Katowice

e-mail:tomasz.ramian@ue.katowice.pl

Krzysztof Kania, Associate Professor, Ph.D.

Faculty of Informatics and Communication

University of Economics in Katowice

e-mail:krzysztof.kania@ue.katowice.pl

\begin{abstract}
This paper is conceptual in nature and presents the assumptions of a holistic approach to corporate real estate management. The approach is based on the imperative of sustainability, which has become a determinant of the proposed Sustainable Corporate Real Estate Management (SCREM) model. Moreover, the authors indicate that in addition to the presence of the sustainability imperative, corporate real estate management requires the integration and formalization of knowledge about the concepts of corporate real estate management (CREM) with those of corporate social responsibility (CSR). This approach is intended to enable the identification and improvement of real estate management processes and, as a result, contribute to more efficient and effective corporate real estate management and continuous and flexible development of enterprises, as well as boosting economic growth and building prosperity for present and future generations.
\end{abstract}

Key words: sustainable development, corporate social responsibility, corporate real estate, real estate management

\section{JEL Classification: G3, M14}

Citation: Ziemba E., Śmietana K., Ramian T., Kania K. 2015, The Concept of a Sustainable Approach to Corporate Real Estate Management, Real Estate Management and Valuation, Vol. 23, No. 4, pp. 85-94.

DOI: $10.1515 /$ remav-2015-0039

\section{Introduction}

Real estate is one of the most important resources of an enterprise and its proper management is a condition for gaining a competitive advantage. Modern Corporate Real Estate Management (CREM) 
should combine elements that, in a sustainable manner, take into account market demands, environmental concerns as well as the needs of users and the business environment. In addition, real estate management should result in achieving the highest efficiency while providing for the varied requirements of corporate stakeholders and considering different perspectives of the time in which the effects of the decisions taken will become apparent.

The above challenges are met by the concept of Sustainable Corporate Real Estate Management (SCREM), which recognizes the interests of both internal and external stakeholder groups. As owners and users of real estate, enterprises are responsible for the impact of their investments as well as the use of buildings on the environment. Their awareness and responsibility should be seen in such formulation of investment strategies and real estate management that considers the environmental, social and cultural expectations of external stakeholders, i.e. society. It is therefore necessary for businesses to adapt new management paradigms and concepts that will enable the optimal use of existing resources and expertise, with a view to maintaining a sustainable and distinctive position in a competitive environment, and at the same time will respect the expectations of external stakeholders related to the well-being of both present and future generations.

The existing research on the concept of "sustainability" as a determinant of modern business management shows that what companies consider important is implementing the principles of corporate social responsibility, environmental management and social management into their management systems (HEJDUK, GRUDZEWSKI 2014, pp. 11-12; GRUDZEWSKI et al., 2013). This approach is referred to as corporate sustainability management and may serve as a foundation for corporate real estate management.

The analysis of relevant literature reveals a research gap on corporate real estate management. Researchers have focused their attention mainly on concepts the application of which is expected to guarantee direct benefits achievable by an enterprise (LIOW, OOI 2004; ŚLIWIŃSKI, ŚLIWIŃSKI 2006; ALI, McGreal, AdAIR, WebB 2008; RYMARZAK 2009; HAYNES, NunNingTON 2010; VARCOE, O'MARA 2011; NOWACKI 2011; NALEPKA 2012; HARRIS, COOKE 2014; MUCZYŃSKI 2015). So far, there has been no proposal of a model that would combine modern management paradigms with sustainable impact on the business environment, and comprise both the short-term and long-term requirements of internal and external stakeholders.

The concept of sustainable corporate real estate management presented in this paper aims to fill the existing research gap. Based on the analysis and synthesis of the proposed approaches to business management (GRUDZEWSKI et al., 2013; JABŁOŃSKI 2013; HEJDUK, GRUDZEWSKI 2014) and corporate real estate management (HAYNES 2012; LORENZ, LÜTZKENDORF 2014; HARRIS, COOKE 2014; MASALSKYTE, ANDELIN, SARASOJA 2014) as well as logical thinking, the authors present the foundations of a new and comprehensive conceptual model of SCREM. The model integrates and expands ideas that are essential for corporate real estate management and sustainable business model, and takes into account the following management dimensions: process-oriented, organizational, financial, behavioral, technological, environmental, social, and cultural. The authors propound a thesis that SCREM requires the improvement of existing corporate real estate management processes and the definition of new ones, with the sustainability imperative being taken into account.

The line of argument in the article is as follows. Firstly, the authors analyze the trends of the development of the concept of CREM, identifying the need for integrating the imperative of sustainability in investment and property management practice. Secondly, they propose the assumptions of the SCREM conceptual model which takes into account both the imperative of sustainability and the process approach. The article ends with a discussion of the implications of the research results and indications as to the direction for further work.

\section{Corporate real estate management development trends - study of relevant literature}

Current global research focuses on corporate real estate (CRE) understood both in the narrow and broad sense. In narrow terms, the term "real estate" is used to describe property used for operational activities of an enterprise. However, in the broad sense, CRE refers to the entirety of the controlled property, regardless of its legal title, or whether it is used for operational activities, or constitutes investment assets. In both perspectives, property in CRE management processes is considered as a financial resource of an enterprise (reflected in the balance sheet) and as tangible assets in the physical dimension, which are to contribute to obtaining the expected performance and achieving the business objectives of an enterprise (HAYNES, NUNNINGTON 2010). In their work on CRE, researchers emphasize 
the need for an integrated management of this resource, which contributes to the achievement of business goals (LIOW, OOI 2004; Ali ET AL., 2008; VARCOE, O'MARA 2011; HARRIS, COOKE 2014). In addition, they emphasize the need to include multiple CRE perspectives in integrated management, e.g. personal property, real estate assets (company's real estate portfolio) and strategic corporate objectives (LINDHOLM 2008; GLATTE 2012).

A change in the perception of the role and objectives of real estate management can currently be observed, and emphasis is put on the importance of real estate as "one of the three most important business resources, alongside people and technology" (HARRIS, COOKE 2014). It is recognized that CRE should be considered as a strategically valuable resource, as it possesses attributes specific for this group of assets, such as a unique character, durability, adequacy, low substitutability, and more (COLLIS, MONTGOMERY 2008). The role of CRE has evolved significantly over the last three decades, from 'space - the external support of economic processes' to a strategic corporate asset. This trend has emerged mainly as a result of dynamic changes within the business environment. The increased role of CRE coincided with increasing globalization, together with the development of ICT and the Internet, which resulted in a number of implications for business processes (ROULAC 2001; HARRIS, COOKE 2014). "The arrival of CRE coincided with the rapidly increasing globalisation of business and the development of ICT and the Internet with their manifold implications for business processes". These changes have been directly affecting decisions made by managers, also in terms of the utilization of corporate real estate (ROULAC 2001).

Systematic studies of relevant domestic literature on the subject create a picture of the evolution of research on CREM. The literature presents consecutive stages of the development of a scientific approach to CRE and its role in an enterprise, as well as in the responsibility borne by managers for its efficient and effective administration (NOURSE, ROULAC 1993; MANNING, ROULAC 1999; ŚLIWIŃSKI, ŚLIWIŃSKI 2006; RYMARZAK 2009; NOWACKI 2011; WOLSKI, ZAŁĘCZNA 2011; ŚMIETANA 2014; MUCZYŃSKI 2015). The research on CREM undertaken in Poland can be described as fragmentary and focused on selected aspects. It does not include sustainable management, and only a few researchers refer to sustainable investment and sustainable real estate. The studies concern:

- socially responsible investing and socially responsible management taking into account the context of sustainable real estate, but with no reference to CRE specifics (MARCINEK 2012; BELNIAK et al., 2013; ŚMIETANA 2014),

- risk of investment in real estate in the context of the corporate social responsibility of real estate market participants (SIEMIŃSKA 2013),

- administration and strategic management procedures of CRE (NALEPKA 2012),

- value of CRE (Konowalczuk, Ramian 2014; Śmietana et al., 2014).

The researchers emphasize that the formulation and application of corporate real estate strategy is an important part of CREM (WILls 2008; HAYNES, NUNINGTON 2010; LiNDHOLM, NENONEN 2006; KONOWALCZUK, RAMIAN, 2014), while recognizing that it should be created in the context of the business strategy of an enterprise. One of the recently issued major publications on the subject also stresses the importance of formulating a real estate strategy for the functioning of the CREM system, indicating that "CREM will need to be able to translate the needs of the business into a coherent supporting strategy; communicate effectively with managers of the business; and adopt techniques to demonstrate the impact of workplace improvement on business performance" - CREM must translate business needs into a coherent supporting strategy, effectively communicate them to managers, and adopt new technologies in order to demonstrate their impact on productivity in the workplace (HARRIS, COOKE 2014, p. 7). Moreover, in his research, Haynes (2012) refers to the integration of the CRE strategy with the corporate strategy, which results in creating a "business environment" that provides an expected level of real estate usefulness, thus also providing the expected level of efficiency. The presented perspectives outline the role of the value of real estate for CREM, understood as corporate real estate management, in order to maximize the added value for an enterprise (KRUMM et al., 2000; EDWARDS, ELLISON 2004; VARCOE, O'MARA 2011). KRUMM et al. (2000) emphasized the double importance of integrated CREM as: managing the corporate real estate portfolio by adjusting both the portfolio and the services to the requirements of the core business in order to achieve maximum added value for enterprises and contribute to the improvement of the overall performance of an enterprise (KRUMM et al. 2000, p. 128). 
Critical studies of the relevant literature have resulted in distinguishing key publications that served as a source of inspiration for the development of a sustainable approach to CREM for the authors. The publication by MASALSKYTE, ANDELIN and SARASOJA (2014) "Modelling sustainability maturity in corporate real estate management" was of fundamental importance. The result of this research is the generic sustainability maturity model for CREM. The model demonstrates the value of implementing sustainable CREM. The result of the research is a classical (standard) maturity model of sustainable CREM. The proposed model is very general, and whilst it does recognize the imperative of sustainability, it fails to discuss it in detail. Moreover, it does not express a holistic approach to CREM that takes into account the concepts of CRS and process management. Therefore, the presented general idea of the model requires expansion and specification.

Another body of work that is of key value to the research is an article by Haynes (2012), in which the author proposes a corporate property management model. The author calls his model $8 * \mathrm{P}$ and identifies eight elements within it: Planet, Position, Purpose, Procurement, Place, Paradigm, Processes, People (HAYNES, 2012). He puts particular emphasis on Planet (sustainability and CSR) and Processes (the activities of the organization). This model, however, is also very general and requires further refining.

The inspiration to undertake research were also publications by German researchers Lorenz and Lützkendorf and the CoreNet Global research team. Lorenz and Lützkendorf's work (2014) "Sustainability Metrics, Translation and Impact on Property Investment and Management" defines the framework of a system for sustainable real estate investment and management. CoreNet Global, the largest worldwide association of CRE experts, undertakes research on new trends in CREM. It mainly concerns the anticipated changes in the nature of business and work, the importance of real estate and changes in the workplace. Its goal is to determine the requirements for CRE by 2020 and studies related to sustainable development and its potential impact on CRE are a significant part of the (CORENET, 2012).

In summary, literature studies indicate that the presence of issues concerning sustainable corporate real estate management is significantly increasing. The presented research, however, is fragmented and limited to individual aspects of CREM (BOYD 2006; LORENZ 2006; LINDHOLM 2008; LAPOSA, VILLUPURAM 2010; LUCAS 2009; MADTITSCH, EBINGER 2011; LÜTZKENDORF, LORENZ 2012; SHARP 2013; WILKINSON, SAYCE, CHRISTENSEN 2015). Only few studies offer a holistic approach to CREM, and these are in the conceptual stage and very general (HAYNES 2012; LORENZ, LÜTZKENDORF 2014). It can also be noticed that, what has not been sufficiently recognized, are CREM processes (LUCAS 2009; MADTITSCH, EBINGER 2011; MASALSKYTE, ANDELIN, SARASOJA 2014). Meanwhile, the imperative of sustainability in corporate real estate management has recently been considered as an integral part of almost every business activity in different industries and sectors, including private and public ones (CORENET 2012; HARRIS, COOKE 2014). Researchers representing various academic circles and international organizations are undertaking further studies whose aim is to develop a comprehensive systems approach to sustainable corporate property management. This research objective has also been adopted by the authors of this paper.

\section{The sustainable approach to corporate real estate management - a conceptual SCREM model}

The proposed SCREM model is compatible with scenarios of anticipated changes in the function and role of CRE outlined in the academic environment. Harris and Cooke (2014) present four scenarios: business as usual, modest change, significant change and transformational change. The last scenario illustrates the concept of integrated corporate resource management, in which all key resources such as ICT, HR and CRE are managed centrally, and it predicts the creation of a new discipline of "organization resource management". The main premise for the creation of such a management model is the integration of processes and systems that do not interact when they work in a functional system (in isolation). This concept combines three groups of resources of a modern organization - space (CRE), employees and technologies, participating in the mission of each organization. The proposed SCREM model is a response to "the integrated business resource management model" and, besides the resources, it integrates concepts which are to ensure the sustainable management of these resources to build long-term sustainability and balance of the company (Fig. 1).

In addition to the imperative of "sustainability", the SCREM concept and model is also based on three other imperatives - "multidimensionality", "holism" and systems thinking (BRYX 2006; ROKITA 2011; ZIEMBA 2013; ZIEMBA 2014; ZIEMBA 2015). The imperative of sustainability in the context of 
SCREM has a much broader meaning that goes beyond interpreting the notion only in terms of ecology (Table 1). It means sustainable - in relation to development, renewable - in terms of resources, and lasting - in terms of growth. It is therefore interpreted as "flexible", "lasting", "continuous", "sustensive", "sustainable", "self-sustainable" and "harmonious". The second major imperative is multidimensionality, which should be understood as "interdisciplinarity", "multilateralism" and "multi-directionality". This means that due to the particular complexity and complicatedness of SCREM phenomena and processes, they all must be considered from the perspective of multiple fields, faculties and disciplines. Their description and explanation requires the application of the achievements of related sciences. A particular imperative to be considered in the concept of SCREM is holism. Overall, according to the holistic theory, SCREM consists of interrelated components (e.g. strategies, objectives, stakeholders, processes, phenomena, and risks). The understanding of principles that dictate SCREM may not be based on the principles governing the components, but rather on components themselves and interactions that occur between them. SCREM is therefore a system with its own objectives and it implements them in one or a number ways. It is also an open system, which means that there is continuous occurrence of various interdependencies between SCREM and its environment. It is based on many concepts which are to provide the sustainability of the system in the economic, environmental, and socio-cultural dimension, to contribute to the improvement of corporate real estate management processes and thus to improve the corporate governance in an enterprise (Table. 1).

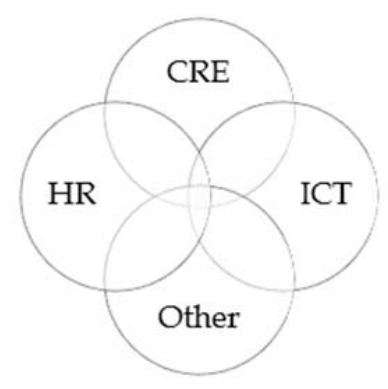

Fig. 1. The integrated business resource management model. Source: CoreNet 2012.

Table 1

Imperative of sustainability and concepts in SCREM

\begin{tabular}{lll}
\hline \multicolumn{1}{c}{ SUSTAINABLE CORPORATE REAL ESTATE MANAGEMENT } \\
\hline \multicolumn{1}{c}{ SCREM } & \multicolumn{1}{c}{ CONCEPTS } & $\begin{array}{l}\text { VBM / CRE VALUE - single } \\
\text { building / portfolio level }\end{array}$ \\
\hline $\begin{array}{l}\text { SCREM as an enabler of economic } \\
\text { growth (economic sustainability) }\end{array}$ & $\begin{array}{l}\text { FM (facility management); REAM } \\
\text { (real estate asset management); } \\
\text { REPM (real estate portfolio } \\
\text { management); PM (process } \\
\text { management) }\end{array}$ & $\begin{array}{l}\text { Market value / Investment } \\
\text { value / Value in use }\end{array}$ \\
\hline $\begin{array}{l}\text { SCREM as an enabler of } \\
\text { environmental protection } \\
\text { (ecological sustainability) }\end{array}$ & $\begin{array}{l}\text { SD (sustainable development); } \\
\text { CSR (corporate social } \\
\text { responsibility); RPI (responsible } \\
\text { property investment) }\end{array}$ & Environmental value \\
\hline $\begin{array}{l}\text { SCREM as an enabler of socio- } \\
\text { cultural development (socio- } \\
\text { cultural sustainability) }\end{array}$ & $\begin{array}{l}\text { SD (sustainable development); } \\
\text { CSR (corporate social } \\
\text { responsibility); RPI (responsible } \\
\text { property investment) }\end{array}$ & $\begin{array}{l}\text { Social value / Public value / } \\
\text { Cultural value (LORENZ, } \\
\text { LÜTZKNDORF, 2014) }\end{array}$ \\
\hline $\begin{array}{l}\text { SCREM as an enabler of corporate } \\
\text { governance (political }\end{array}$ & $\begin{array}{l}\text { ESG (environmental, social, } \\
\text { governance) }\end{array}$ & Image value \\
\hline
\end{tabular}


sustainability)

Source: own study.

SCREM combines various concepts of real estate management. A systemic approach is reflected in the concept of facility management (FM). FM is defined as the integration of processes in terms of property and infrastructure management, aiming to provide the functionality of the construction environment through the integration of people, places, processes and technologies (IFMA, http://www.ifma.org/). Standardized and integrated processes are intended to support and improve the efficiency of the core business of an enterprise. Management concepts are to contribute to the efficient use of CRE, taking into account the perspective of individual facilities - operational facility management (FM) and a strategic approach that includes the perspective of a part or the entire company real estate portfolio - real estate asset management (REAM) and real estate portfolio management (REPM). Comprising the highlighted concepts SCREM will include the dimension bound with management by value. It will be a system that allows creating and maintaining value by improving the management of business processes in order to increase the productivity of CRE (property performance), understood as: functional quality, technical quality, cultural \& social quality, economic performance, and environmental performance. This approach requires distinguishing between different categories of property values based on the concept of value based management (VBM), in addition to values commonly analyzed in CREM: market value, investment value, or use value. SCREM also refers to: environmental value, social value, public value, cultural value, and image value (Table 1$)$.

The creation of a sustainable construction environment in the processes of CRE development and management is to be based on assumptions of the concept of sustainable development (SD). Sustainable development is understood as meeting the needs of the society while taking into account the limitations of the natural environment of the planet and enabling the realization of the aspirations of future generations. As a response to the challenges of SD, social responsibility (SR) constitutes an expansion of this idea and remains closely associated with it. It refers to corporate social responsibility (CSR) of an enterprise towards its stakeholders, including the society and the environment, and the realization of specified targets is to contribute to maximizing the contribution of the organization to sustainable development. The concept of social responsibility, considered in accordance with ISO 26000 guidelines (EN/ISO 26000:2012) in the context of the functioning of a socially responsible company, assumes its willingness to take into account social and environmental issues in the decisionmaking process and decision-related activities, and the disclosure of the impact of those decisions and activities on the society and the environment. This means an attitude representing the ethical and transparent activities of the company, contributing to sustainable development in accordance with the applicable law and remaining consistent with the accepted norms of conduct. In the real estate management system, it will mean the implementation of the Responsible Property Investment (RPI) and sustainable management with the stated objectives of environmental sustainability, social responsibility and environmental, social, and governance (ESG).

SCREM requires the improvement of existing real estate management processes and defining new ones. Hence the necessity to include the process approach in the SCREM model and to formalize the knowledge of the SCREM processes in the form of a process maturity model (see: e.g. Kania, 2013). The process approach aims to result in a more efficient use of corporate real estate, as well as in taking into account the socio-cultural aspects and their neutral impact on the environment.

The authors also indicate a particular importance of the use of ICT in the sustainable corporate real estate management system. In this system, ICT is a factor that stimulates activities in the following areas:

- environmental protection,

- economic growth,

- social and cultural development,

- corporate governance.

Overall, the SCREM conceptual model includes the following components: CRE, real estate management concepts and other pillars of corporate sustainability management, processes, internal and external stakeholders and ICT (Fig. 2). 
The proposed approach assumes creating a sustainable environment where the (often conflicting) expectations of various stakeholder groups of the company are respected. The key stakeholders of SCREM include: internal stakeholders (managers, employees) and external stakeholders (close business environment - local communities and the society as a whole). Internal stakeholders expect support for the implementation of business objectives, while the environment expects the protection of the interests of present and future generations. Table 2 summarizes various groups of stakeholders and management concepts that are an integral part of the proposed model.

ICT

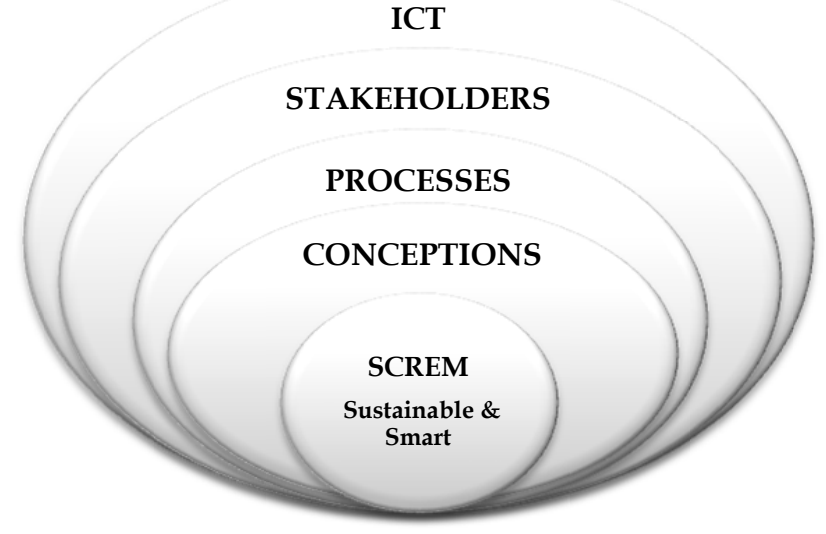

Fig. 2. SCREM conceptual model. Source: own study.

Table 2

Stakeholders and concepts in SCREM

\begin{tabular}{|c|c|c|c|c|}
\hline \multirow{2}{*}{ Stakeholders } & \multicolumn{2}{|c|}{ Internal } & \multicolumn{2}{|c|}{ External } \\
\hline & Employees & Managers & Environment & Society \\
\hline \multirow{3}{*}{$\begin{array}{l}\text { Concepts associated } \\
\text { with preferred } \\
\text { values } \\
\text { VBM value based } \\
\text { management }\end{array}$} & $\begin{array}{l}\text { Flexible working } \\
\text { styles - the } \\
\text { intelligent }\end{array}$ & $\begin{array}{l}\text { Integrated business } \\
\text { resource } \\
\text { management }\end{array}$ & $\begin{array}{l}\text { Sustainable } \\
\text { development CRE - } \\
\text { Sustainable design }\end{array}$ & $\begin{array}{l}\text { Sustainability in the } \\
\text { context of } \\
\text { protecting the }\end{array}$ \\
\hline & $\begin{array}{l}\text { workplace (HAYNES } \\
\text { 2010) }\end{array}$ & $\begin{array}{l}\text { (HARRIS, COOKE, } \\
2014)\end{array}$ & $\begin{array}{l}\text { (WILKINSON, SAYCE, } \\
\text { CHRISTENSEN, 2015) }\end{array}$ & $\begin{array}{l}\text { interests of future } \\
\text { generations } \\
\text { (MARTINET 2012; } \\
\text { WILKINSON, SAYCE, } \\
\text { CHRISTENSEN, 2015) }\end{array}$ \\
\hline & Processes approach & FM, REAM, REPM & $\mathrm{SD}, \mathrm{CSR}$ & RPI, ESG \\
\hline
\end{tabular}

Source: own study.

The SCREM model is an open one. The multiplicity of its components and connections between them, as well as the large number of interdependencies inside the model and its relationships with the environment, requires in-depth studies of both the components and dependencies between them. This, in turn, requires answering the following key questions:

- What emerging business, social, cultural and technological trends and management concepts affect SCREM?

- Who are the main SCREM stakeholders and what are their goals?

- What are the major and minor SCREM objectives?

- What principles and processes characterize SCREM and result in its development?

- What are the key factors for the success of SCREM?

- How can SCREM value be measured?

SCREM is expected to contribute to the development of a sustainable business model, as it meets the requirements of corporate sustainability management, which envisages the introduction of the rule of ensuring the application of corporate social responsibility in the management systems. It is an 
extension of the concept of "sustainability enterprises" - businesses of the future - whose authors refer to the sustainability of an entity understood as the ability to continue to operate in a rapidly changing environment and keeping up with changing expectations of stakeholders.

\section{Conclusions}

To the best of the authors' knowledge, there are currently no proposals of a holistic approach to SCREM. This is due to several reasons. Firstly, many of the concepts, phenomena and issues in the field of SCREM are characterized by a high degree of turbulence. Secondly, the SCREM paradigm is not yet well-established. Thirdly, there is too little awareness of the importance of the application of the sustainability imperative and the latest management concepts in CREM. Also lacking is knowledge about the potential benefits and risks of SCREM. It is therefore necessary to intensify research on the subject. Further research and scientific discussions on various kinds of concepts, models and methodological assumptions which constitute a platform for the formulation of theories describing the reality of SCREM is essential.

With regard to the above, the authors of this article have proposed the principles of sustainable corporate real estate management. The combination of the concept of corporate social responsibility with the imperative of sustainability and the process approach to corporate property management results in an approach that goes beyond the currently existing proposals in this regard. The research results will help discover and understand the rules and regularities that govern processes associated with sustainable corporate real estate management, provide a model for the improvement and evaluation of these processes, and serve as a scientific basis for the construction, development and evaluation of a corporate real estate management system. In the authors' opinion, a corporate real estate management system that takes into account the holistic approach will enable the creation and maintenance of values by improving the management of business processes with a view to increasing the efficiency of corporate real estate, tailored to pursuing the business objectives of an organization. In the proposed system, CRE value shall be considered in various dimensions, including broadly analyzed productivity and economic efficiency, and will take into account the context of the environment, environmental performance, and socio-cultural quality.

Further research work aims at developing the conceptual model proposed in this article. It will take the form of a detailed maturity model, which will be a useful record of the knowledge of the processes, both for scientists dealing with real estate management issues, as well as managers intending to improve the real estate management processes in their organizations. This model will be used to examine the quality of property management processes in Polish enterprises and identify factors that stimulate or inhibit the improvement of these processes. At the same time, methodological assumptions will be put forward for creating a process management system that will be useful in improving corporate real estate management.

\section{References}

Ali Z., McGreal S., AdaIR A., WebB J.R., 2008, Corporate Real Estate Strategy: a Conceptual Overview, Journal of Real Estate Literature, 16(1), pp. 3-21.

BelniAK S., GŁUSZAK M., ZIĘBA M., 2013, Budownictwo ekologiczne. Aspekty ekonomiczne (Ecological Construction. Economic Aspects.), Wydawnictwo Naukowe PWN, Warszawa.

BRYX M., 2006, Rynek nieruchomości, system i funkcjonowanie (Real Estate Market, System and Functioning) Poltext, Warszawa (Poltext, Warsaw).

BOYD T., 2006, Evaluating the Impact of Sustainability on Investment Property Performance, Central Queensland University and Queensland University of Technology, Australia.

Collis D. J., MONTGOMERY C.A., 2008, Competing on Resources, Harvard Business Review, (JulyAugust), pp. 140-50.

CORENET (2012). The Corporate Real Estate 2020, Sustainability Report, www.corenetglobal.org.

EDWARDS V., ELLISON L., 2004, Corporate Property Management: Aligning Real Estate with Business Strategy. Blackwell Publishing, Oxford, Kindle Edition.

GLATTE T. (2012). The Importance of Corporate Real Estate Management in Overall Corporate Strategies. CoreNet Global.

GRUDZEWSKI W.M., HejDUK I.K., SANKOWSKA A., WAŃTUCHOWICZ M., 2013, Sustainability w biznesie czyli przedsiębiorstwo przysztości. Zmiany paradygmatów i koncepcji zarządzania (Sustainability in 
Business or the Company of the Future. Changes in Management Paradigms and Concepts), Poltext, Warszawa.

HARRIS R., COOKE H., 2014, Is Corporate Real Estate at a Crossroads? Journal of Corporate Real Estate, $16 / 4$, pp. $275-289$.

HAYNES B., 2010, Aligning Corporate Real Estate to Meet the Changing Demands of Human Resource Management,

http://www.eres.org/eres2010/contents/papers/eres2010_141_Haynes_ALIGNING_CORPORA TE_R.pdf.

HAYNES B., NunNingtON N., 2010, Corporate Real Estate Asset Management: Strategy and Implementation, Taylor \& Francis. Oxford, Kindle Edition.

HAYNES B.P., 2012, Corporate Real Estate Asset Management: Aligned Vision, Journal of Corporate Real Estate, Vol. 14 No. 4, 2012, pp. 244-254, http:/ / dx.doi.org/10.1108/JCRE-10-2012-0022.

HEJDUK I.K., GRUDZEWSKI W.M., 2014, Koncepcja sustainablity wyzwaniem wspótczesnego zarzadzania (The Concept of Sustainability as a Challenge of Modern Management), in: Koncepcja sustainability wyzwaniem wspótczesnego zarządzania (The Concept of Sustainability as a Challenge of Modern Management), ed. I. K. Hejduk, Oficyna Wydawnicza SGH, Warszawa, 2014, pp. 11-28.

JABŁOŃSKI A., 2013, Modele zrównoważonego biznesu w budowie dtugoterminowej wartości przedsiębiorstw z uwzględnieniem ich społecznej odpowiedzialności (Sustainable Business Models in Building Long-term Value, of Enterprises, Taking into Sccount their Social Responsibility), Difin, Warszawa (Difin, Warsaw).

KANIA K., 2013, Doskonalenie zarzadzania procesami biznesowymi w organizacji z wykorzystaniem modeli dojrzałości i technologii informacyjno-komunikacyjnych (Improvement of Business Process Management in an Organization Using Maturity Models and ICT), Wydawnictwo Uniwersytetu Ekonomicznego w Katowicach, Katowice (University of Economics in Katowice Publishing House, Katowice).

KonOWALCZUK J., RAmiAn T., 2014, The Value of CRE in the Formulation and Implementation Process of Real Estate Strategies in a Company, "Real Estate Management and Valuation", 22(1), pp. 58-68.

KRumm P., DewUlf G., DE JONGE H., 2000, What is Corporate Real Estate? Successful Corporate Real Estate Strategies, ARKO Publishers, Nieuwegein.

LAPOSA S.P., VILluPURAM S., 2010, Corporate Real Estate and Corporate Sustainability Reporting: an Examination and Critique of Current Standards, Journal of Sustainable Real Estate, 2(1), pp. 23-49.

LiNDHOLM A.L., NENONEN S., 2006, A Conceptual Framework of CREM, Journal of Corporate Real Estate, 8(3), pp. 108-119.

LiNDHOLM, A.L., 2008, A Constructive Study on Creating Core Business Relevant CREM Strategy and Performance Measures, Facilities, 26(7/8), pp. 343-358.

LiOW K.H., OOI J.T.L., 2004, Does Corporate Real Estate Create Wealth for Shareholders? Journal of Property Investments and Finance, 22(5), pp. 386-400.

LORENZ D.P., 2006, The Application of Sustainable Development Principles to the Theory and Practice of Property Valuation, Dissertation, Universität Karlsruhe, Karlsruhe.

LUCAS, M.T., 2009, Understanding Environmental Management Practices: Integrating Views from Strategic Management and Ecological Economics, Business Strategy and the Environment, 19(8), pp. 543-556.

LÜTZKENDORF T., LORENZ D., 2012, Integrating Sustainability Issues into Property Risk Assessment - an Approach to Communicate the Benefits of Sustainable Buildings, Universität Karlsruhe, School of Economics, Karlsruhe, http:/ / www.cce.ufl.edu/wp-content/uploads/2012/08/Lutzkendorf.pdf.

MAdritsch T., EBINGER M., 2011, Performance Measurement in Facility Management - The Environment Management Maturity Model BEM3, Research Journal of Economics, Business and IT, 2, pp. 4-10.

MARCINEK K., 2012, Społecznie odpowiedzialne inwestowanie na rynku nieruchomości (Socially Responsible Investing in the Property Market), Zeszyt Naukowy Studia Ekonomiczne No. 104, Wydawnictwo UE w Katowicach pp. 163-185.

MARTINET V., 2012, Economic Theory and Sustainable Development. What Can We Preserve for Future Generations? Routledge Taylor \& Francis Group.

Nourse H. O., RoulaC S. E., 1993, Linking Real Estate Decisions to Corporate Strategy, Journal of Real Estate Research, Vol. 8, No. 4, pp. 475-494.

MANNING C., Roulac S.E.,1999, Corporate Real Estate Research within the Academy. Journal of Real Estate Research: 1999, Vol. 17, No. 3, pp. 265-279.

MASAlskyte R., Andelin M., SARASOJA A.L., VentovuOri T., 2014, Modelling Sustainability Maturity in Corporate Real Estate Management, Journal of Corporate Real Estate, 16(2), pp. 126-139. 
MUCZYŃSKI A., 2015, An Integrated Approach to Real Estate (Portfolio) Management, Real Estate Management and Valuation, Vol. 23, No. 2, pp. 5-16.

NALEPKA A., 2012, Identyfikacja systemu zarządzania nieruchomościami przedsiębiorstwa (Identification of a Corporate Real Estate Management System), Studia i Materiały TNN, 20(3), pp. 5-16.

NOWACKI P., 2011, Nieruchomości w przedsiębiorstwie a wartość przedsiębiorstwa (Real Estate in Enterprise and the Value of Enterprise), Studia i Materiały TNN, 19(2), pp. 189-202.

PKN (2012). EN/PN-ISO 26000:2012 Wytyczne dotyczace społecznej odpowiedzialności (Guidelines on Social Responsibility), http:/ / www.pkn.pl/_licencja PKN dla UE w Katowicach, z dn. (from) 09.01.2014.

ROKITA J., 2011, Myślenie systemowe w zarzadzaniu organizacjami (Systems Thinking in Managing Organizations), Uniwersytet Ekonomiczny, Katowice.

RoulAC S., 2001, Corporate Property Strategy is Integral Part to Corporate Business Strategy, Journal of Real Estate Research, 22 (1/2), pp. 129-152.

RYMARZAK M., 2009, Zarządzanie nieruchomościami przedsiębiorstw w Polsce (Corporate Real Estate Management in Poland), CeDeWu, Warszawa.

SHARP D., 2013, Risks Ahead: the Transformation of the Corporate Real Estate Function, Journal of Corporate Real Estate, 15(3/4), pp. 231-243.

SIEMIŃSKA E., 2013, Ryzyka inwestowania i finansowania na rynku nieruchomości w kontekście etyki i społecznej odpowiedzialności (Risks of Investing and Financing in the Real Estate Market in the Context of Ethics and Social Responsibility), Wydawnictwo Naukowe UMK, Torun.

ŚLIWIŃSKI A., ŚLIWIŃSKI B., 2006, Facility Management, Wydawnictwo C.H. Beck, Warszawa.

ŚMIETANA K., 2014, Idea odpowiedzianych inwestycji w nieruchomości w dziatalności deweloperskiej (The Edea of Responsible Investment in Real Estate in the Property Development Business), in: Zarzacdzanie i Finanse.

ŚMIETANA K., KONOWAlCZUK J., MASZCZYK A., 2014, Rating in the Assessment of Investment Property, Real Estate Management and Valuation, 22(2), pp. 98-107.

UNEP_FI (2014). Sustainability Metrics, Translation and Impact on Property Investment and Management, Lützkendorf T., Lorenz D., www.unepfi.org.

VARCOE B., O'MARA M. (2011). Corporate Real Estate Impact on Enterprise Success. Regus Global Report.

WilKINSON S.J., SAYCE S.L., CHRISTENSEN P.H., 2015, Developing Property Sustainably, Routledge Taylor \& Francis Group.

Wills P.C., 2008, Corporate Real Estate Practice in Australia, Journal of Corporate Real Estate, 10(1), pp. 40-53.

WOLSKI R., ZAŁĘCZNA M., 2011, Nieruchomości w zasobach przedsiębiorstwa - potencjat do wykorzystania (Real Estate in Company Resources - Potential for Use), Studia i Materiały TNN, 19(1), pp. 131-141.

ZIEMBA E., 2013, The Holistic and Systems Approach to the Sustainable Information Society, Journal of Computer Information Systems, 54(1), pp. 106-116.

ZIEMBA E., 2014, Discussion on the Sustainable Information Society, Business Informatics, 1(31), pp. 13-25.

ZIEMBA E., 2015, (ed.) Towards Sustainable Information Society - People, Business and Public Administration Perspectives, Cambridge Scholars Publishing, Cambridge (in print). 